DOI: https://doi.org/10.36910/6775-2524-0560-2021-42-12

УДК 02:004.942

${ }^{1}$ Палка Олег Вікторович, аспірант, https://orcid.org/0000-0001-5607-279X

${ }_{1}^{1}$ Станько Андрій Андрійович, аспірант,

https://orcid.org/0000-0002-5526-2599

${ }^{1}$ Шимчук Григорій Валерійович, старший викладач, заступник зав. каф. комп'ютерних наук.

https://orcid.org/0000-0003-2362-7386

${ }^{2}$ Герасимчук Олег Олександрович, директор.

https://orcid.org/0000-0003-3029-695X

${ }^{1}$ Тернопільський національний технічний університет імені Івана Пулюя, м. Тернопіль, Україна.

${ }^{2}$ Відокремлений структурний підрозділ «Технічний фаховий коледж Луцького національного технічного університету», м. Луцьк, Україна.

\title{
ЗАПОБІГАННЯ ПОШИРЕННЯ КОРОНАВІРУСНОЇ ІНФЕКЦІЇ У «РОЗУМНИХ MICTAX»
}

Палка О. В., Станько А. А., Шимчук Г. В., Герасимчук О.О. Запобігання поширення коронавірусної інфекції у «розумних містах». На сьогоднішній день увесь світ все ще веде боротьбу із пандемією COVID-19. Уряди різних країн та організації вирішують, як саме можна використовувати нові технології для полегшення її наслідків та як можна уникнути або мінімізувати майбутні пандемії. Використання технологій розумного міста широко обговорювалось для зменшення ризику COVID-19. Тому в цій статті розглядаються реалізовані програмні рішення у різних країнах та пропонується модель інформаційної системи, яка б забезпечувала розумну охорону здоров'я.

Ключові слова: IoT, розумне місто, пандемія, COVID-19, математичне моделювання, застосунок, інформаційна система, діаграма, прецедент, актор.

Палка О. В., Станько А. А., Шимчук Г. В., Герасимчук О.О Предотвращение распространения коронавирусной инфекции в «умных городах». Пока весь мир все еще борется с разрушительными последствиями пандемии COVID-19, правительства и организации решают, как можно использовать новые технологии для облегчения ее последствий и как можно избежать или минимизировать будущие пандемии. Использование технологий умного города широко обсуждался для уменьшения риска COVID-19. Поэтому в этой статье рассматриваются реализованы программные решения в разных странах, и предлагается модель информационной системы, которая бы обеспечивала разумное здравоохранение.

Ключевые слова: IoT, умный город, пандемия, COVID-19, математическое моделирование, приложение, информационная система, диаграмма, прецедент, актер.

Palka O., Stanko A., Shymchuk H., Herasymchuk O. Preventing the spread of coronavirus infection in "smart cities". While the world is still struggling with the devastating effects of the COVID-19 pandemic, governments and organizations are deciding how new technologies can be used to alleviate their effects and how future pandemics can be avoided or minimized. The use of smart city technologies has been widely discussed to reduce the risk of COVID-19. Therefore, this article discusses the implemented software solutions in different countries, and proposes a model of an information system that would provide smart health care.

Keywords: IoT, smart city, pandemic, COVID-19, mathematical modeling, application, information system, diagram, precedent, actor.

\section{Постановка наукової проблеми.}

Термін «Інтернет речей» (IoT) вперше був уведений у презентації Кевіна Ештона про впровадження ідентифікації радіочастот (RFID) у компанії Procter \& Gamble для управління ланцюгами поставок [1]. IoT - це передова технологія, яка може зв'язати всі розумні об'єкти разом у мережі без взаємодії людини [2]. Простіше кажучи, будь-який об'єкт, який можна підключити до Інтернету для подальшого моніторингу або передачі даних, може бути пристроєм ІоТ [3].

Протягом останніх років ІоТ отримала переконливий дослідницький грунт як нову тему дослідження в найрізноманітніших академічних та виробничих дисциплінах, особливо в галузі охорони здоров'я. Революція ІоТ перекроює сучасні системи охорони здоров'я, включаючи технологічні, економічні та соціальні перспективи. Він розвиває системи охорони здоров'я від звичайних до більш персоналізованих, завдяки яким пацієнтів можна легше діагностувати, лікувати та контролювати.

IоT все частіше стає життєво важливою технологією в системах охорони здоров'я, де вона може забезпечити менші витрати, кращу якість послуг та вдосконалений досвід користувачів [4-7]. У результаті його широких можливостей, включаючи відстеження, ідентифікацію та аутентифікацію, та збір даних, експоненціальне зростання ІоТ у галузі охорони здоров'я зросте із 72 млрд. дол. США у 2020 р. до 188 млрд. дол. у 2025 р. [2, 8].

Сучасна глобальна проблема пандемії, спричинена новим важким респіраторним синдромом коронавірусу 2, є найбільшою глобальною кризою в галузі охорони здоров'я 3 часів спалаху пандемії 
іспанського грипу у 1918 році [9]. Згідно з останніми даними Всесвітньої організації охорони здоров'я (BOO3), станом на початок лютого 2021 року (на рис. 1) кількість підтверджених випадків COVID-19 становить 105 мільйонів, від недуги загинуло більш, ніж 2 мільйони людей [10].

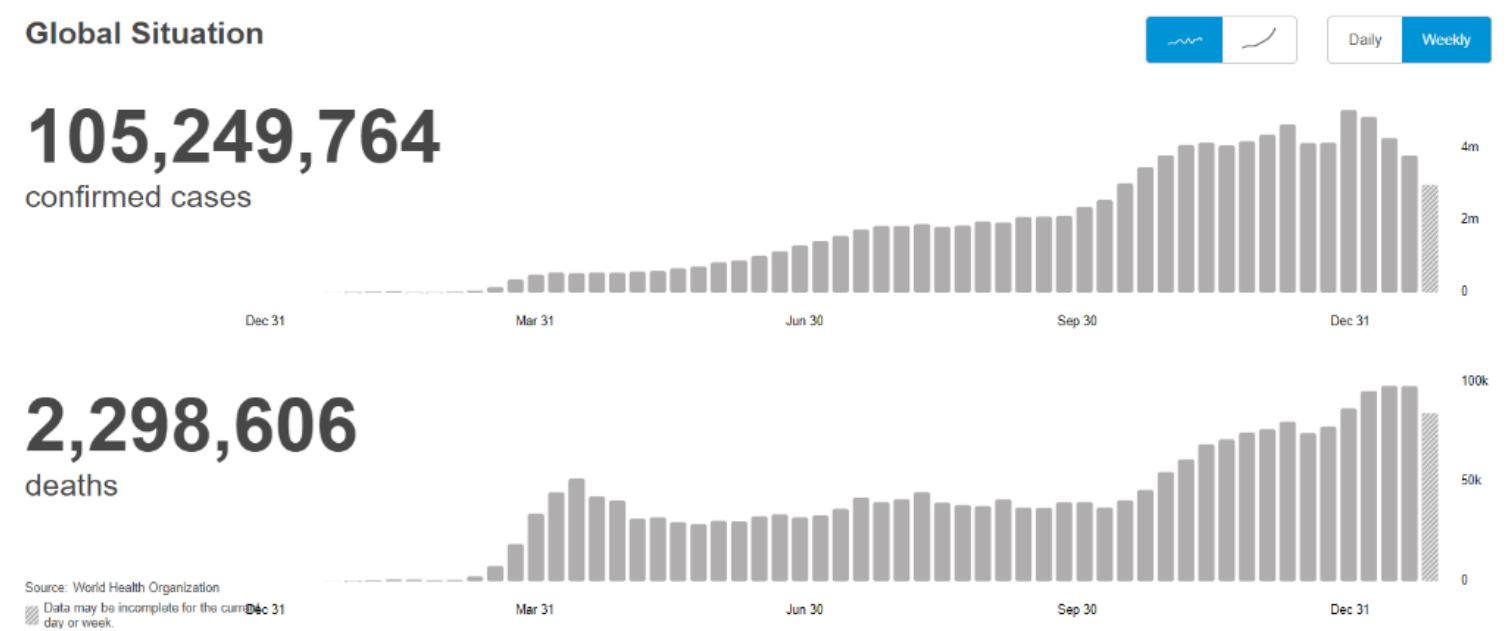

Рис. 1. Потижневий аналіз захворюваності на COVID-19 у світі станом на лютий 2021 року [10]

Ця хвороба має симптоми, подібні до грипу, такі як лихоманка, кашель і втома, які важливо розпізнати для ранньої діагностики [11]. Інкубаційний період COVID-19 триває від 1 до 14 днів. Дивно, але пацієнт без будь-яких симптомів може бути носієм вірусу COVID-19 і наражати на небезпеку інших [12]. Більше того, період одужання від цієї хвороби варіюється і залежить від віку пацієнта, основних станів тощо, але загалом триває від 6 днів до 41 дня [13].

Технології ІоТ у відповідь на COVID-19 застосовується у трьох фазах хвороби - ранній діагностиці, ізоляційному періоду і періоду після одужання.

Розумні міста - це бачення розвитку міст для інтеграції безлічі ІКТ-рішень для управління активами міста для створення стійкого середовища, підвищення якості життя і підвищення ефективності та економічної цінності [14]. Кількість нових продуктів та додатків ІоТ за останні роки зросла в геометричній прогресії. Саме тому метою дослідження є проведення аналізу використання мобільних застосунків для мінімізації ризику зараження та контролю над дотриманням самоізоляції мешканцями міст та країн загалом, а також проектування моделі інформаційної системи для України.

\section{Аналіз досліджень.}

Сучасна епідеміологічна ситуація у світі вимагає вчасного виявлення осередку захворюваності жителів міст із застосуванням ІоТ для забезпечення та розвитку їх розумності. Найбільшого застосування здобули мобільні додатки та ГІС-системи поширення коронавірусної інфекції у певних країнах та світі загалом. У даній роботі здійснимо аналіз використання мобільних додатків із цією метою у сімох країн.

Додаток «COVID Symptom Tracker», який використовується у Великобританії та США, надає дані щодо факторів ризику, прогнозних симптомів, клінічних результатів та географічної точки доступу. Його запуск відбувся у Великобританії 24 березня 2020 року та у США 29 березня 2020 року та набрав понад 2,8 мільйонів користувачів станом на 2 травня 2020 року [15]. Їх ініціатива пропонує доказ концепції перероблення існуючих підходів для забезпечення швидкого масштабування епідеміологічного збору та аналізу даних, що є критичним для реагування на дані, пов'язані з цим завданням охорони здоров'я.

За аналізом зібраних даних щодо симптомів COVID близько у 2 мільйонів користувачів (включаючи медичних працівників) з усієї Великобританії та Сполучених Штатів автори [16] зробили висновок, що поширеність комбінацій симптомів (три або більше), включаючи втому та кашель 3 подальшим діареєю, лихоманкою та/або аносмією, передбачає позитивну перевірку тесту на SARS-CoV-2. Математичне моделювання на основі статистичних даних дозволяє прогнозувати географічні точки виникнення на 5-7 днів раніше до офіційних звітів органів охорони здоров'я.

У березні 2020 року MobiHealthNews повідомив [17], що уряд Сінгапуру запустив мобільний застосунок «TraceTogether», щоб допомогти підтримати та доповнити поточні зусилля 3 відстеження контактів у національній державі, намагаючись зменшити поширення COVID-19. 
TraceTogether працює, обмінюючись сигналами Bluetooth на відстані між телефонами, щоб виявити інших учасників TraceTogether в безпосередній близькості. Записи таких зустрічей зберігаються локально на телефоні кожного користувача.

Згідно із заявою Управління розумних націй при кабінеті прем’єр-міністра в Сінгапурі, близько 1,8 мільйона людей завантажили застосунок TraceTogether, але «цього недостатньо», оскільки застосунок наразі не охоплює населення, що перебуває в цифровому рахунку, включаючи літніх та маленьких дітей, які можуть не мати смартфонів.

Інша проблема полягає в тому, що застосунок не працює надійно на пристроях $\mathrm{OOS}$ i може спричиняти значну витрату ресурсу акумулятора, що стримуватиме користувачів iPhone до його використання.

У зв'язку з цим різні заражені країни пропонують цифровий процес відстеження контактів 3 мобільним застосунком, використовуючи різні технології, такі як Bluetooth, система глобального позиціонування (GPS), соціальний графік, контактні дані, мережевий API, дані мобільного відстеження, транзакції з карткою даних та фізичною адресою системи. Процес цифрового відстеження контактів може виконуватися практично в режимі реального часу і набагато швидше порівняно з нецифровою системою. Всі ці цифрові програми призначені для збору індивідуальних персональних даних, які будуть проаналізовані інструментами машинного навчання (MH) та штучного інтелекту (Ш) для відстеження людини, яка вразлива до нового вірусу через їх недавню контактну мережу.

На даний момент понад 36 країн (Австралія, Австрія, Чехія, Китай та інші) успішно застосували цифрове відстеження контактів, використовуючи централізоване, децентралізоване або гібридне використання обох методів, щоб зменшити зусилля та підвищити ефективність традиційних процесів діагностики охорони здоров'я [18].

У Польщі влада автоматично створює акаунти для громадян, які повернулися з закордону у застосунку «Kwarantanna domowa».

31 квітня застосування цього додатку стало обов'язковим для всіх осіб, що проходять 14-денний карантин [19]. Принцип роботи застосунка схожий з українським «Дій вдома». Громадяни, які перебувають на карантині, у відповідь на надісланий запит мають зробити селфі. Завдяки геолокації та системи розпізнавання обличчя встановлюється особа, та звіряється адреса із зазначеною у формі напередодні. Міністерство цифровізації Польщі стверджує, що завдяки застосунку користувачі також можуть отримати швидкий доступ до гарячої лінії зв'язку із соціальною службою, яка може надавати ліки або продукти харчування в окремих випадках.

У Німеччині використовується мобільний застосунок «Передача даних про коронавірус» («СoronaDatenspende»), розроблений інститутом імені Роберта Коха.

Він призначений для збору даних щодо поширення коронавірусу у ФРН. Використання його добровільне і можливе під псевдонімом [20]. Користувачам необхідно ввести свій поштовий індекс, стать, вік, зріст і вагу. Дані використовують для створення онлайн мапи Німеччини, де рівень зараження можна буде побачити за поштовим індексом. Дослідників цікавить частота пульсу користувачів у спокої, а також інформація про їхні періоди активності та сну. По ним застосунок може розпізнати типові симптоми пов'язані з Covid-19.

У Китаї мешканці користуються додатком «Код здоров’я Alipay». Його розробила китайська компанія, що займається інтернет-торгівлею «Alibaba». Після завантаження застосунок пропонує відповісти на ряд запитань, і потім за своїм алгоритмом визначає, чи має людина залишатися вдома. Застосунок схвалений урядом та $є$ обов'язковим для використання. У співпраці з владою Китаю компанія розробила систему, яка присвоює $\mathrm{QR}$ коди трьох кольорів мільйонів китайських користувачів онлайн гаманця «Alipay»:

- $\quad$ Зелений - дозволяє вільне пересування, зокрема, у метро;

- Жовтий - рекомендує тижневий домашній карантин;

- $\quad$ Червоний - два тижні самоізоляції.

Застосунок передає дані про геолокацію користувача та колір присвоєного QR коду до поліції. За даними розробника [21] його використовують вже 700 мільйонів громадян Китаю.

«Ви були поруч з тим, хто має позитивний тест на коронавірус. Ви повинні негайно самоізолюватись вдома!». Таке повідомлення на смартфони вже отримали сотні ізраїльтян. Прем'єр Ізраїлю Беньямін Нетаньягу дозволив службі внутрішньої розвідки використовувати глобальну базу даних і відстежувати переміщення тих, хто заразився коронавірусом [21]. Створена мапа випадків захворювань. Мобільний застосунок показує присутність можливого носія інфекції поблизу власника мобільного телефону з цим застосунком. Програма відстежує геолокацію телефону та інформує про наближення до потенційно 
небезпечного місця, не чекаючи запиту. Використовується супутникова система навігації. Застосунок зберігає інформацію про переміщення людини.

Міністерство цифрової трансформації України створило застосунок «Дій вдома» для контролю обов'язкової самоізоляції.

Застосунок має контролювати тих, хто вже є носієм вірусу, або може потенційно ним стати. Перелік таких громадян визначають епідеміологи Міністерства охорони здоров'я. Ці громадяни надають письмову згоду на встановлення застосунку та обробку своїх даних. Застосунок упродовж двох тижнів надсилає користувачам до десяти PUSH-повідомлень на день, у відповідь на повідомлення впродовж 15 хвилин треба зробити селфі. Під час здійснення фото зчитується геолокація. Якщо впродовж 15-ти хвилин користувач нічого не надсилає - іде сповіщення до поліції. Правоохоронці можуть зателефонувати або приїхати до людини на самоізоляції за адресою, яку та добровільно надала напередодні [21].

У таблиці 1 наведено порівняльний аналіз вищезгаданих мобільних додатків, які використовуються при боротьбі із COVID-19.

Таблиця 1. Порівняльний аналіз мобільних додатків

\begin{tabular}{|c|c|c|c|c|c|c|c|c|c|c|}
\hline \multirow{2}{*}{ 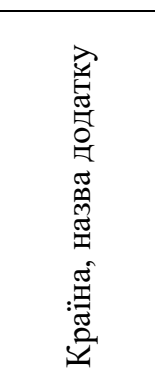 } & \multirow{2}{*}{ 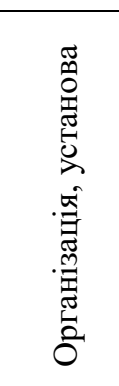 } & \multirow[b]{2}{*}{ 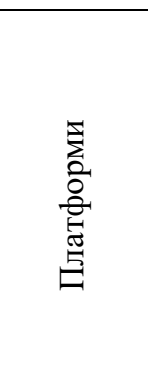 } & \multicolumn{5}{|c|}{ Призначення } & \multicolumn{3}{|c|}{$\begin{array}{c}\text { Технологія } \\
\text { для збору } \\
\text { даних }\end{array}$} \\
\hline & & & 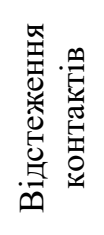 & 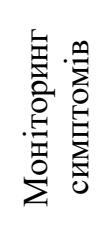 & 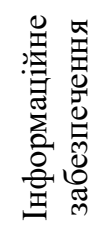 & 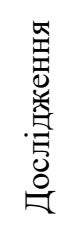 & 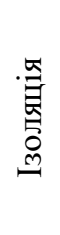 & $\begin{array}{l}\frac{5}{0} \\
\frac{0}{0} \\
\frac{0}{\bar{n}}\end{array}$ & $\tilde{0}$ & 罣 \\
\hline $\begin{array}{l}\text { Велика } \\
\text { Британі } \\
\text { я } \\
\text { COVID } \\
\text { Symptom } \\
\text { Tracker }\end{array}$ & $\begin{array}{l}\text { Прива } \\
\text { тна } \\
\text { органі } \\
\text { зація }\end{array}$ & $\begin{array}{l}\text { iOS та } \\
\text { Android }\end{array}$ & & + & & & & & & 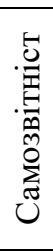 \\
\hline $\begin{array}{l}\text { Сінгапу } \\
\mathbf{p} \\
\text { TraceTog } \\
\text { ether }\end{array}$ & Уряд & $\begin{array}{l}\text { iOS } \mathrm{Ta} \\
\text { Android }\end{array}$ & + & & & & & + & & \\
\hline $\begin{array}{l}\text { Польща } \\
\text { Kwaranta } \\
\text { nna } \\
\text { domowa }\end{array}$ & Уряд & $\begin{array}{l}\text { iOS та } \\
\text { Android }\end{array}$ & & & + & & + & & + & 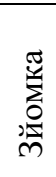 \\
\hline $\begin{array}{l}\text { Німеччи } \\
\text { на } \\
\text { Corona- } \\
\text { Datenspe } \\
\text { nde }\end{array}$ & Уряд & $\begin{array}{l}\text { iOS та } \\
\text { Android }\end{array}$ & & + & & + & & & & 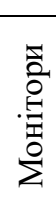 \\
\hline $\begin{array}{l}\text { Китай } \\
\text { Код } \\
\text { здоров’я } \\
\text { Alipay }\end{array}$ & $\begin{array}{l}\text { Прива } \\
\text { тна } \\
\text { органі } \\
\text { зація, } \\
\text { схвале } \\
\text { ний } \\
\text { урядо } \\
\text { м }\end{array}$ & $\begin{array}{l}\text { iOS } \mathrm{Ta} \\
\text { Android }\end{array}$ & + & & & & + & & + & \\
\hline $\begin{array}{l}\text { Ізраїль } \\
\text { Щит } \\
\end{array}$ & Уряд & $\begin{array}{l}\text { iOS та } \\
\text { Android }\end{array}$ & + & & + & & & & + & \\
\hline $\begin{array}{l}\text { Україна } \\
\text { Дій } \\
\text { вдома }\end{array}$ & Уряд & $\begin{array}{l}\text { iOS та } \\
\text { Android }\end{array}$ & & & + & & + & & + & 荧 \\
\hline
\end{tabular}


Варто зауважити, що більшість із них розроблено урядом (у 5 із 7 країн), усі додатки підтримуються сучасними операційними системами для смартфонів, більшість із них використовуються для відстеження контактів потенційно хворої/хворої людини (у 3 із 7) та контролю дотримання режиму ізоляції (у 3 із 7). Найпоширенішою технологією для збору даних - $\epsilon$ GPS-давач.

Щодо українського досвіду, то додаток «Дій вдома» $є$ аналогом до польського додатку «Домашній карантин» як за функціональним призначенням так і за технологією для збору даних.

Виклад основного матеріалу й обгрунтування отриманих результатів дослідження.

Для забезпечення максимального контролю та дотримання усіх функціональних призначень серед виділених у таблиці 1 вирішено спроектувати інформаційну систему «Мобільна інформаційна система моніторингу поширення вірусів».

На рис. 2 наведено ії множину акторів.

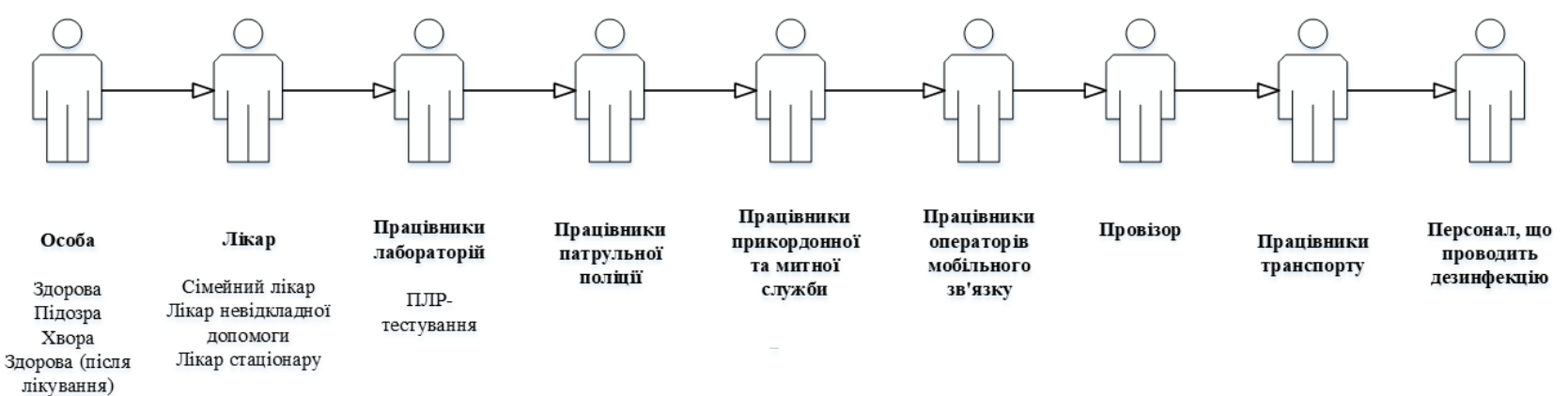

Рис. 2. Актори інформаційної системи

Розглядаються такі актори в системі:

- Особа (здорова особа, особа з підозрою, інфікована особа і здорова особа після лікування).

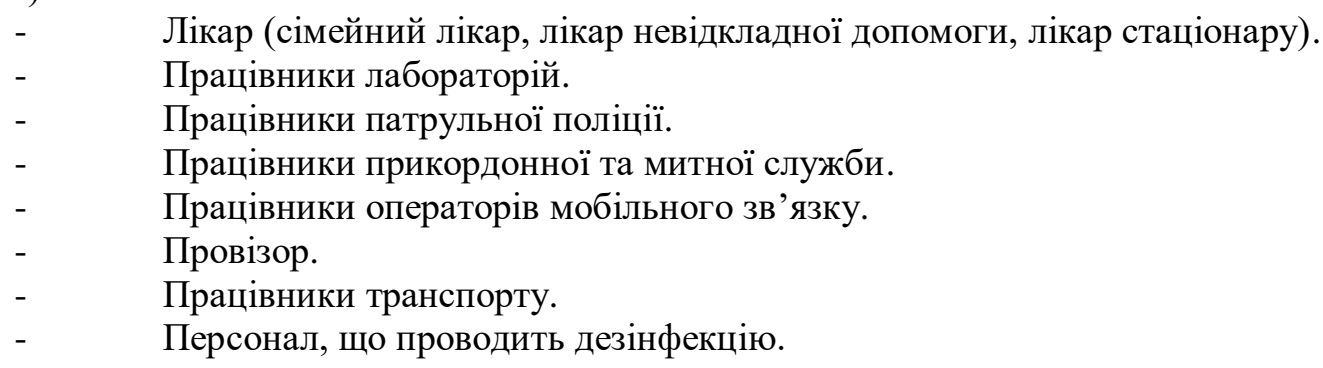

Кожен актор в системі відіграє невід’ємну роль в ситуації з коронавірусом та розкриває свої процеси в подоланні нової пандемії COVID-19.

На рис. 3 наведено діаграму прецедентів для актора «Особа». 


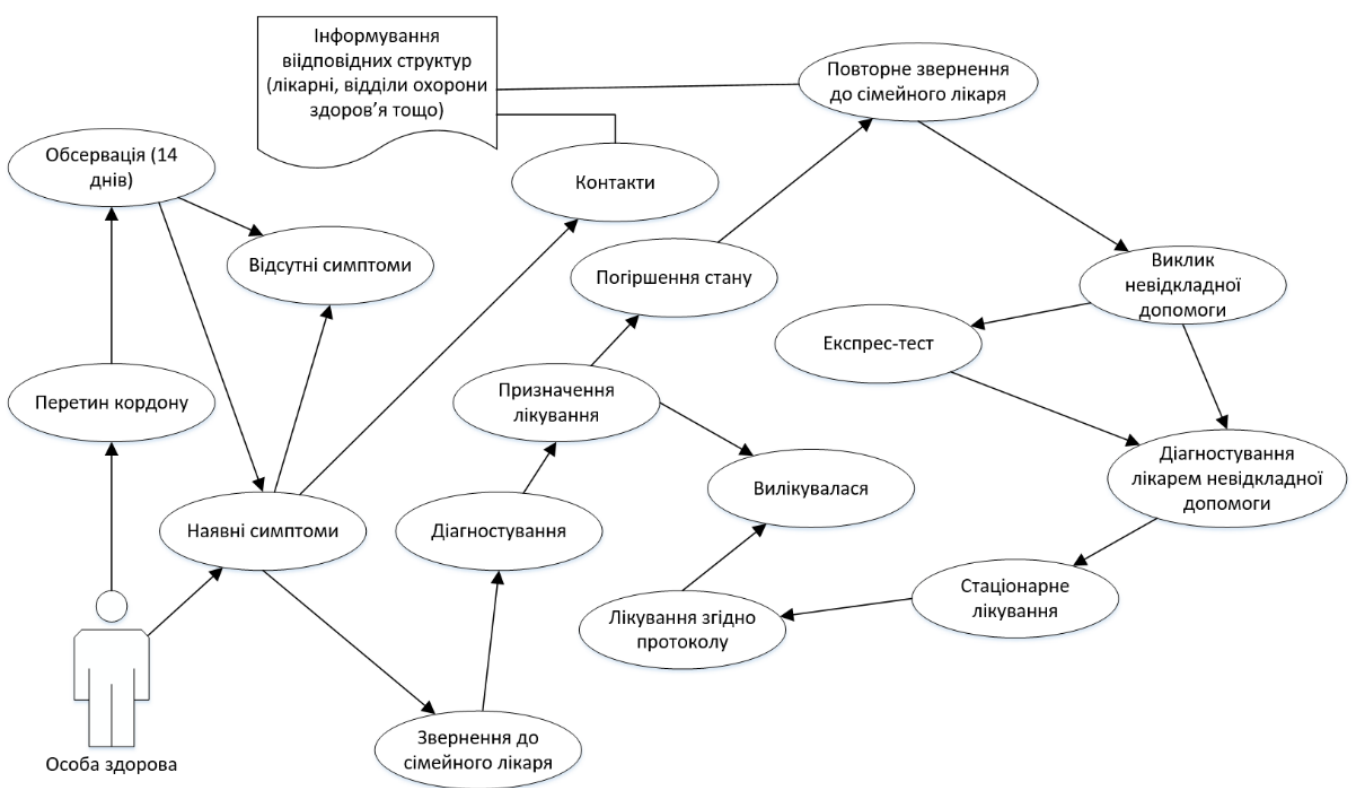

Рис. 3. Діаграма прецедентів для актора «Особа»

Якщо особа перетинає кордон, вона вважається потенційно можливим хворим. Тому вона повинна пройти 14-денну обсервацію. Якщо ж у неї не має симптомів і термін обсервації проходить, то вона може повернутись до нормального режиму життя. Якщо особа відчуває якісь симптоми 3 можливих при захворюванні COVID-19, бажано залишатися вдома, потрібно в телефонному режимі звернутися до сімейного лікаря або, по можливості, щоб лікар прийшов до пацієнта, використовуючи всі рекомендації щодо запобігання зараженню.

Важливою складовою дослідження і аналізу всієї ситуації з коронавірусом є діяльність лікаря.

На рис. 4 наведено діаграму прецедентів для актора «Лікар».

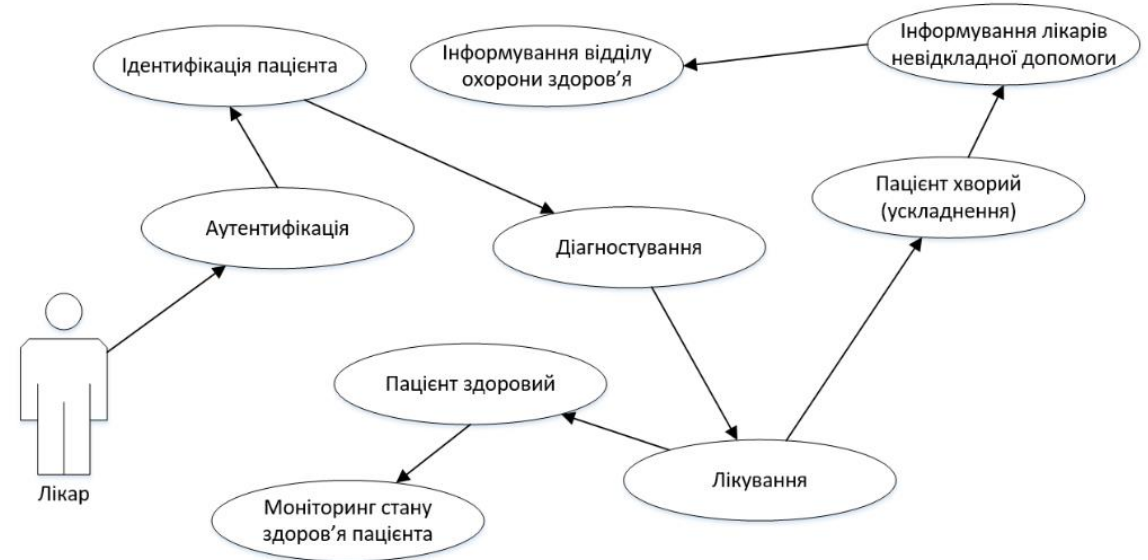

Рис. 4. Діаграма прецедентів для актора «Лікар»

Сімейний лікар, поспілкувавшись із пацієнтом, оцінює ситуацію і дає конкретні поради щодо подальших дій. На рис. 5 наведено діаграму прецедентів для актора «Сімейний лікар». 


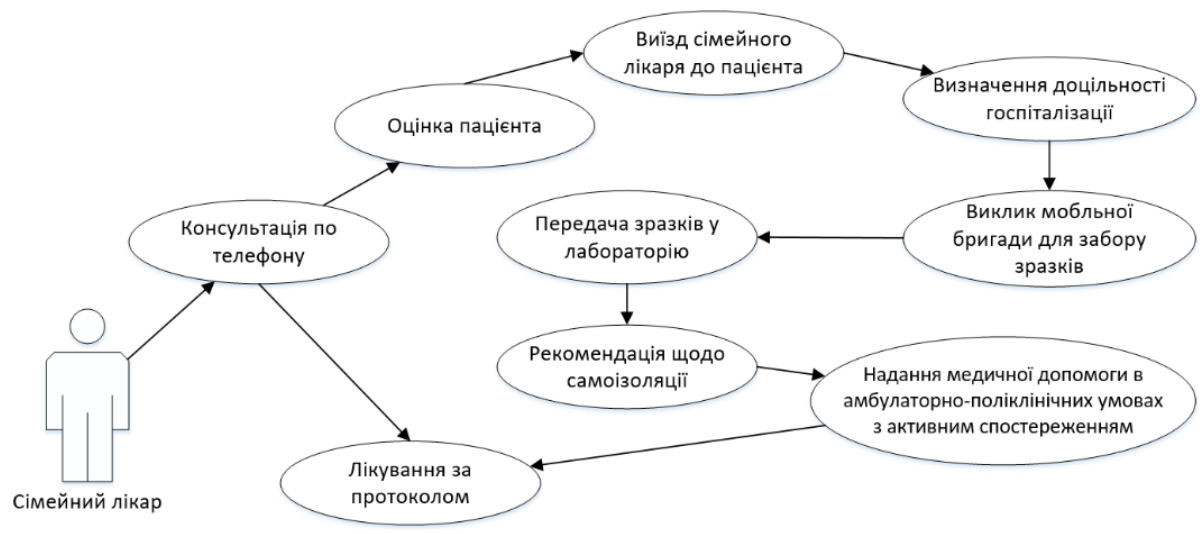

Рис. 5. Діаграма прецедентів для актора «Сімейний лікар»

Якщо пацієнт має сімейного лікаря, його необхідно проінформувати. Якщо лікаря немає, то до пацієнта потрібно направити мобільну бригаду для взяття тесту методом ПЛР.

На рис. 6 наведено діаграму прецедентів для актора «Прикордонна та митна служба».

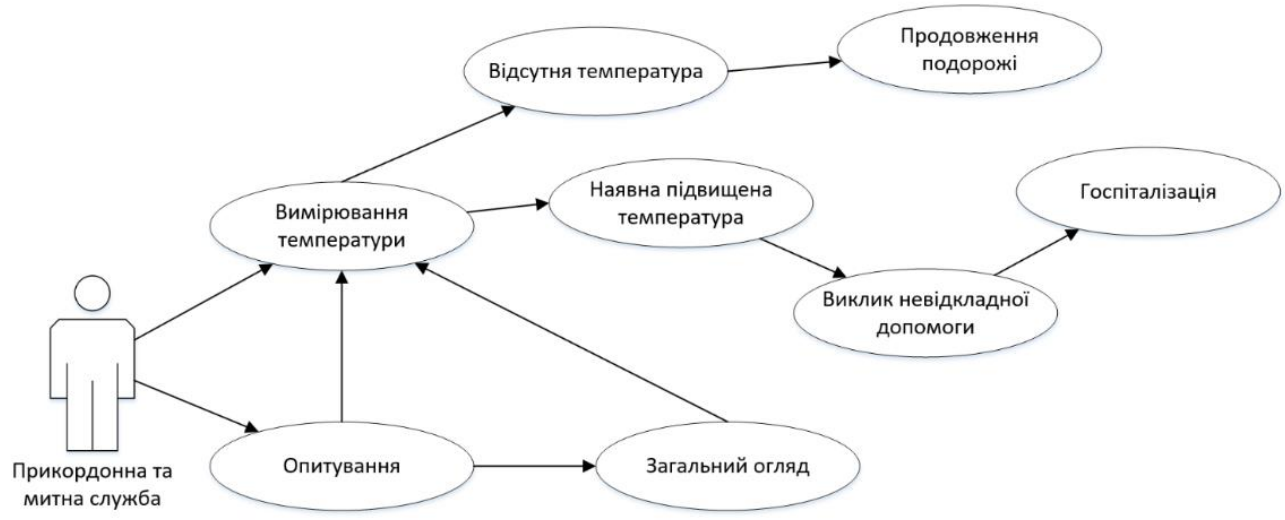

Рис. 6. Діаграма прецедентів для актора «Прикордонна та митна служба»

При перетині українського кордону, кожну особу зустрічає прикордонний патруль. На кожному українському пункті пропуску працює санітарно-контрольний пост. Завдання прикордонників не лише стежити за правовим та законним перетином кордону, але й, в умовах карантину, запобігати поширенню COVID-19. Тому у них $є$ завдання максимально бути пильними та убезпечити не тільки себе від зараження, але і забезпечити людям безпечний перетин кордону та подальше перебування на території України.

При зустрічі з прикордонниками проходить загальний огляд та опитування подорожуючих, щоб зрозуміти як вони почуваються, з яких країн вони повертаються.

Поліцейські здійснюють охорону місць обсервації і території медичних закладів, де перебувають особи із захворюванням чи підозрою на COVID-19.

На рис. 7 наведено діаграму прецедентів для актора «Патрульна поліція».

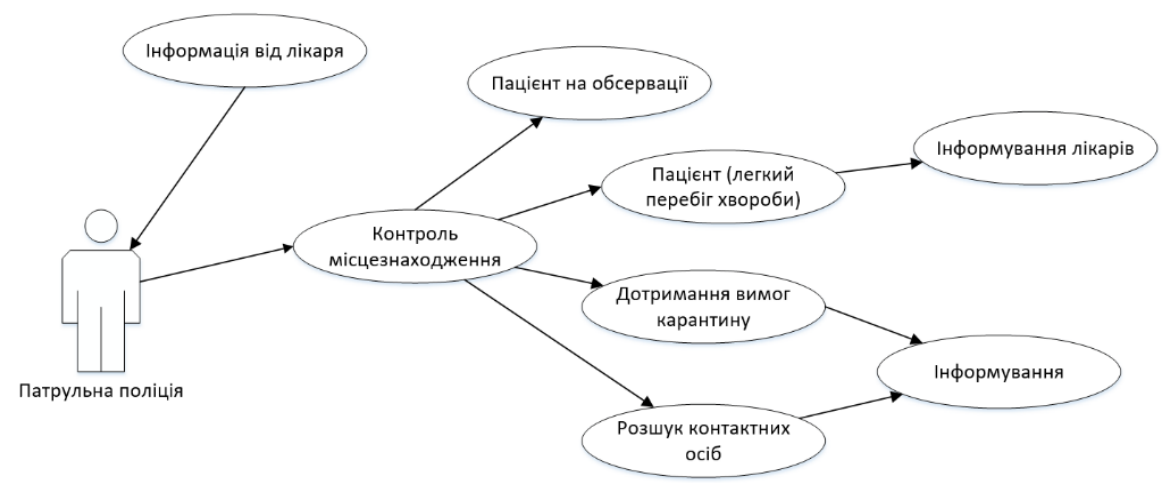

Рис. 7. Діаграма прецедентів для актора «Патрульна поліція» 
Безпосередньо фармацевт повинен уточнити наявні симптоми і на їх основі консультувати щодо лікарських засобів або повідомити про звернення до лікаря. На рис. 8 наведено діаграму прецедентів для актора «Провізор».

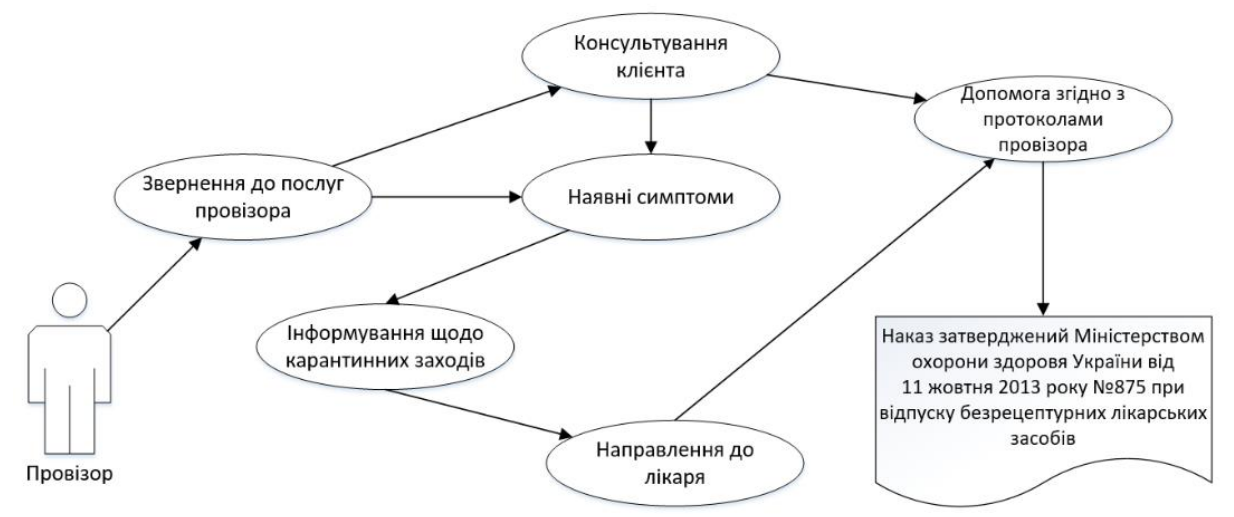

Рис. 8. Діаграма прецедентів для актора «Провізор»

На рис. 9 наведено діаграму прецедентів для актора «Оператор мобільного зв’язку».

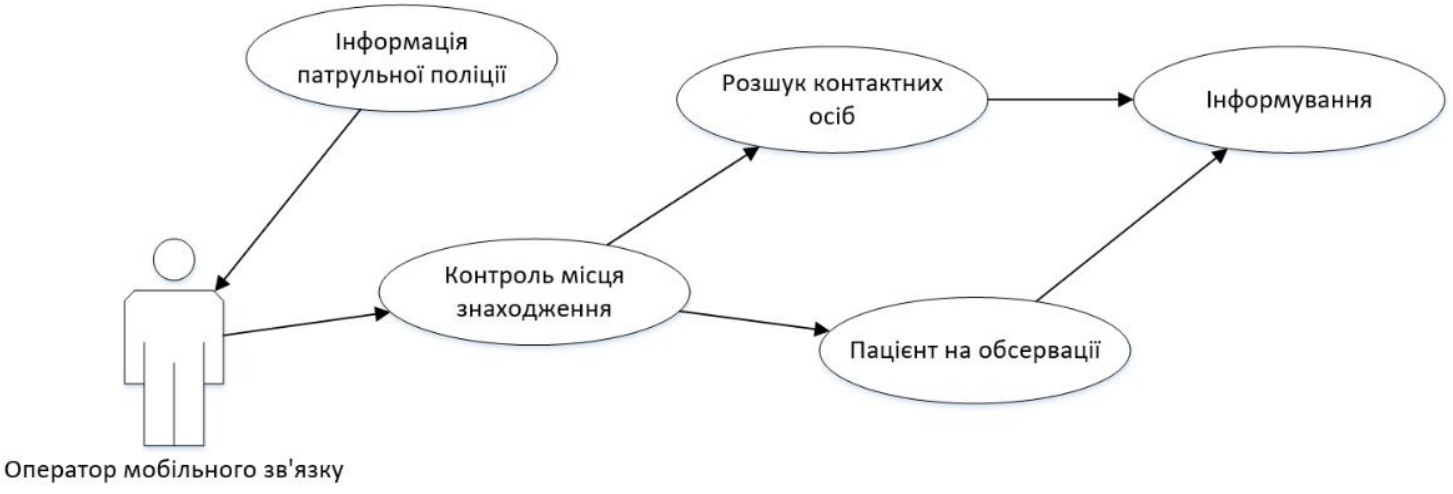

Рис. 9. Діаграма прецедентів для актора «Оператор мобільного зв'язку»

Для забезпечення контролю пересування потенційно хворих або хворих осіб за запитом поліції оператори мобільного зв’язку можуть надати координати поточного місця перебування.

\section{Висновки та перспективи подальшого дослідження.}

Проведений авторами аналіз досліджень 3 питань впровадження мобільних додатків для контролю стану особи у «розумних» містах в період пандемії коронавірусу засвідчив їх актуальність та практичну цінність, адже їх використання передбачає додатковий захист для здорової людини та контроль за етапами лікування хворого.

Запропоновані авторами підходи до формування групи акторів системи, а також функціональний розподіл кожного із акторів системи дозволяє в подальшому реалізувати IC, яка б сприяла зменшенню кількості хворих, та активно реалізовувати у місті елементи «розумності» і зменшити навантаження на систему охорони здоров'я.

\section{Список бібліографічного опису}

1. Ештон, Кевін. “Ця річ ‘Інтернету речей’.” Журнал RFiD, вип. 22, № 7, 2009, с. 97-114.

2. Арафат Алі, Гешам, Зозо Хасан та Махмуд М. Бадаві. “Інтернет речей (ІоТ): визначення, виклики та останні напрямки досліджень.” Міжнародний журнал комп'ютерних програм, вип. 128, №1, жовтень 2015 р., с. 37-47., doi:10.5120/ijca2015906430.

3. ХаддадПаджу, Хамед, Алі Дехгантанья, Реза М.Парізі, Мохаммед Аледхарі та Хадіс Каріміпур. “Опитування безпеки Інтернету речей: вимоги, виклики та рішення.” Інтернет речей, листопад 2019 р., с. 100129., doi:10.1016/j.iot.2019.100129.

4. Да Коста, Кріштіану Андре, Крістіан Ф. Паслуоста, Бьорн Ескоф’є, Деніз Бандейра Да Сільва та Родріго Да Роза Рігі. “Інтернет про здоров'я: до інтелектуального моніторингу життєво важливих ознак у лікарняних палатах.” Штучний інтелект у медицині, вип. 89, 2018, с. 61-69., doi:10.1016/j.artmed.2018.05.005.

5. Ріазул Іслам, С. М., Даехан Квак, Мд Хумаун Кабір, Махмуд Хоссейн і Кюнг-Суп Квак. “Інтернет речей для охорони здоров’я: всебічне опитування." Доступ IEEE, вип. 3, 2015, с. 678-708., doi:10.1109/access.2015.2437951. 
6. Ху, Фанг, Дан Сі та Шаоу Шень. “Про застосування Інтернету речей у галузі медицини та охорони здоров’я.” 2013 Міжнародна конференція IEEE з питань зелених обчислень та комунікацій та IEEE Інтернет речей та IЕEЕ Кібер, фізичні та сочіальні обчислення, 2013,, doi:10.1109/greencom-ithings-cpscom.2013.384.

7. Ці, Цзюнь, По Ян, Гейон Мін, Олівер Амфт, Фен Донг і Ліда Сю. "Розширений Інтернет речей для персоніфікованих систем охорони здоров'я: опитування.” Поширені та мобільні обчислення, вип. 41, 2017, с. 132-149.

8. “ІоТ на ринку охорони здоров'я.” Фірма з дослідження ринку, www.marketsandmarkets.com/Market-Reports/iot-healthcaremarket-160082804.html.

9. Лавлейс-молодший, Берклі. “Вчені кажуть, що коронавірус як мінімум такий смертельний, як пандемія грипу 1918 року.” $C N B C$, www.cnbc.com/berkeley-lovelace-jr/.

10. “Інформаційна панель ВООЗ про коронавірус (COVID-19).” Всесвітня організація охорони здоров'я, covid19.who.int/.

11. “Симптоми коронавірусу.” Центри з контролю та профілактики захворювань, www.cdc.gov/coronavirus/2019-ncov/symptomstesting/symptoms.html.

12. “COVID-19: Коли на карантин.” Центри з контролю та профілактики захворювань, www.cdc.gov/coronavirus/2019-ncov/ifyou-are-sick/quarantine.html.

13. Ванг, Вейєр, Цзяньмін Тан і Фаньцян Вей. “Оновлене розуміння спалаху нового коронавірусу 2019 року (2019-NCoV) у місті Ухань, Китай.” Журнал медичної вірусологї̈, вип. 92, № 4, 2020, с. 441-447.

14. Альгрен, Бенгт, Маркус Хіделл та Едіт К.-Х. Нгай. “Інтернет речей для розумних міст: взаємодія та відкриті дані.” Iнтернетобчислення IEEE, вип. 20, № 6, 2016, c.52-56., doi:10.1109/mic.2016.124.

15. Чан, Ендрю Т., Девід А. Дрю, Лонг Х. Нгуен, Аміт Д. Джоші, Веньцзе Ма, Чуан-Го Го, Чун-Хан Ло, Раадж С. Мехта, Сохі Квон, Даніель Р. Сікаві, Марина В. Магічева-Гупта, Захра С. Фатехі, Жаклін Дж. Флін, Брайанна М. Леонардо, Крістін М. Альберт, Габріелла Андреотті, Лора Е. Бін-Фрімен, Біджал А. Баласубраманян, Джон С. Браунштейн, Фіона Брюйнсма, Енні Н. Коуан, Анусіла Дека, Майкл Е. Ернст, Джейн К. Фігейредо, Пол В. Френкс, Крістофер Д. Гарднер, Ірен М. Гобріал, Крістофер А. Хейман, Джанет Е. Холл, Сандра Л. Демінг-Халверсон, Бренда Кірпач, Джеймс В. Лейсі, Лоїк Ле Маршан, Кетрін Р. Марінак, Марія Олена Мартінес, Роджер Л. Мілн, Енн М. Мюррей, Денис Наш, Джулі Р. Палмер, Альпа В. Патель, Лінн Розенберг, Дейл П. Сендлер, Шріла В. Шарма, Пастух Х. Шурман, Лінн Р. Уілкенс, Хорхе Е. Чаварро, А. Хізер Еліассен, Хайме Е. Харт, Дже Хі Канг, Карестан Ч. Кенен, Лора Д. Кубзанські, Лорелей А. Муччі, Себастьян Урселін, Джанет В. Річ-Едвардс, Мінганг Сонг, Мейр Дж. Стампер, Клер Дж. Стів, Вальтер К. Вільттт, Йонатан Вульф, і Тім Спектор. “Консорціум пандемічної епідеміології коронавірусу (СОРЕ): заклик до дії.” Епідеміологія раку Біомаркери та профілактика, вип. 29, № 7, 2020, с.1283-1289. doi:10.1158/1055-9965.epi-20-0606.

16. Тінг, Даніель Шу, Лоуренс Карін, Віктор Дзау та Тянь Ю. Вонг. “Цифрові технології та COVID-19.” Природна медицина, вип. 26, ном. 4, 2020, с. 459-461.

17. Стівенс, Халлам і Монамі Бхадра Хейнс. “ТraceTogether: реакція на пандемію, демократія та технології. ” Східноазіатська наука, технології та суспільство: Міжнародний журнал, вип. 14, № 3, 2020, с. 523-532.

18. Лалмуанавма, Самуель, Джамал Хуссейн та Лалрінфела Чакчхуак. “Застосування машинного навчання та штучного інтелекту для пандемії Covid-19 (SARS-CoV-2): огляд.” Хаос, солітони та фрактали, вип. 139, 2020, с. 110059.

19. “Додаток 'Kwarantanna Domowa' Обов’язковий Для Всіх, Хто Перебуває На Карантині.” UAinKrakow.pl, 2 Кві. 2020 , uainkrakow.pl/dodatok-kwarantanna-domowa-oboviazkovyi-dlia-vsikh-khto-perebuvaie-na-karantyni/.

20. Німецька хвиля. “Коронавірус: У ФРН Представили Новий Додаток Для Збору Даних: DW: 07.04.2020.” DW.COM, www.dw.com/ru/коронавирус-в-фрг-представили-новое-приложение-для-сбора-данных/a-53048057.

21. Німецька хвиля. "Смартфон Проти Коронавірусу: Як Контролюють Самоізоляцію На Прикладі 5 Kраїн (22.04.2020): DW: 22.04.2020." DW.COM, www.dw.com/uk/смартфон-проти-коронавірусу-як-контролюють-самоізоляцію-на-прикладі-5-країн22042020/av-53209342.

\section{References}

1. Ashton, Kevin. “That 'Internet of Things' Thing.” RFiD Journal, vol. 22, no. 7, 2009, pp. 97-114.

2. Arafat Ali, Hesham, Zozo Hassan, and Mahmoud M Badawy. "Internet of Things (IoT): Definitions, Challenges and Recent Research Directions." International Journal of Computer Applications, vol. 128, no. 1, Oct. 2015, pp. 37-47., doi:10.5120/ijca2015906430.

3. HaddadPajouh, Hamed, Ali Dehghantanha, Reza M. Parizi, Mohammed Aledhari, and Hadis Karimipour. "A Survey on Internet of Things Security: Requirements, Challenges, and Solutions.” Internet of Things, Nov. 2019, p. 100129., doi:10.1016/j.iot.2019.100129.

4. Da Costa, Cristiano André, Cristian F. Pasluosta, Björn Eskofier, Denise Bandeira Da Silva, and Rodrigo Da Rosa Righi. "Internet of Health Things: Toward Intelligent Vital Signs Monitoring in Hospital Wards.” Artificial Intelligence in Medicine, vol. 89, 2018, pp. 61-69., doi:10.1016/j.artmed.2018.05.005.

5. Riazul Islam, S. M., Daehan Kwak, Md Humaun Kabir, Mahmud Hossain, and Kyung-Sup Kwak. "The Internet of Things for Health Care: A Comprehensive Survey.” IEEE Access, vol. 3, 2015, pp. 678-708., doi:10.1109/access.2015.2437951.

6. Hu, Fang, Dan Xie, and Shaowu Shen. "On the Application of the Internet of Things in the Field of Medical and Health Care." 2013 IEEE International Conference on Green Computing and Communications and IEEE Internet of Things and IEEE Cyber, Physical and Social Computing, 2013, doi:10.1109/greencom-ithings-cpscom.2013.384.

7. Qi, Jun, Po Yang, Geyong Min, Oliver Amft, Feng Dong, and Lida Xu. "Advanced Internet of Things for Personalised Healthcare Systems: A Survey." Pervasive and Mobile Computing, vol. 41, 2017, pp. 132-149.

8. "IoT in Healthcare Market." Market Research Firm, www.marketsandmarkets.com/Market-Reports/iot-healthcare-market160082804.html.

9. Lovelace Jr., Berkeley. "Scientists Say the Coronavirus Is at Least as Deadly as the 1918 Flu Pandemic ." CNBC, www.cnbc.com/berkeley-lovelace-jr/.

10. "WHO Coronavirus (COVID-19) Dashboard." World Health Organization, covid19.who.int/.

11. "Symptoms of Coronavirus." Centers for Disease Control and Prevention, www.cdc.gov/coronavirus/2019-ncov/symptomstesting/symptoms.html.

12. "COVID-19: When to Quarantine." Centers for Disease Control and Prevention, www.cdc.gov/coronavirus/2019-ncov/if-you-aresick/quarantine.html. 
13. Wang, Weier, Jianming Tang, and Fangqiang Wei. "Updated Understanding of the Outbreak of 2019 Novel Coronavirus (2019-NCoV) in Wuhan, China." Journal of Medical Virology, vol. 92, no. 4, 2020, pp. 441-447.

14. Ahlgren, Bengt, Markus Hidell, and Edith C.-H. Ngai. "Internet of Things for Smart Cities: Interoperability and Open Data." IEEE Internet Computing, vol. 20, no. 6, 2016, pp. 52-56., doi:10.1109/mic.2016.124.

15. Chan, Andrew T., David A. Drew, Long H. Nguyen, Amit D. Joshi, Wenjie Ma, Chuan-Guo Guo, Chun-Han Lo, Raaj S. Mehta, Sohee Kwon, Daniel R. Sikavi, Marina V. Magicheva-Gupta, Zahra S. Fatehi, Jacqueline J. Flynn, Brianna M. Leonardo, Christine M. Albert, Gabriella Andreotti, Laura E. Beane-Freeman, Bijal A. Balasubramanian, John S. Brownstein, Fiona Bruinsma, Annie N. Cowan, Anusila Deka, Michael E. Ernst, Jane C. Figueiredo, Paul W. Franks, Christopher D. Gardner, Irene M. Ghobrial, Christopher A. Haiman, Janet E. Hall, Sandra L. Deming-Halverson, Brenda Kirpach, James V. Lacey, Loïc Le Marchand, Catherine R. Marinac, Maria Elena Martinez, Roger L. Milne, Anne M. Murray, Denis Nash, Julie R. Palmer, Alpa V. Patel, Lynn Rosenberg, Dale P. Sandler, Shreela V. Sharma, Shepherd H. Schurman, Lynne R. Wilkens, Jorge E. Chavarro, A. Heather Eliassen, Jaime E. Hart, Jae Hee Kang, Karestan C. Koenen, Laura D. Kubzansky, Lorelei A. Mucci, Sebastien Ourselin, Janet W. Rich-Edwards, Mingyang Song, Meir J. Stampfer, Claire J. Steves, Walter C. Willett, Jonathan Wolf, and Tim Spector. "The COronavirus Pandemic Epidemiology (COPE) Consortium: A Call to Action." Cancer Epidemiology Biomarkers \& Prevention, vol. 29, no. 7, 2020, pp. 1283-1289., doi:10.1158/1055-9965.epi-20-0606.

16. Ting, Daniel Shu, Lawrence Carin, Victor Dzau, and Tien Y. Wong. "Digital Technology and COVID-19." Nature Medicine, vol. 26, no. 4, 2020, pp. 459-461.

17. Stevens, Hallam, and Monamie Bhadra Haines. "TraceTogether: Pandemic Response, Democracy, and Technology." East Asian Science, Technology and Society: An International Journal, vol. 14, no. 3, 2020, pp. 523-532.

18. Lalmuanawma, Samuel, Jamal Hussain, and Lalrinfela Chhakchhuak. "Applications of Machine Learning and Artificial Intelligence for Covid-19 (SARS-CoV-2) Pandemic: A Review." Chaos, Solitons \& Fractals, vol. 139, 2020, p. 110059.

19. "The 'Kwarantanna Domowa' app is a must for anyone who is in quarantine." UAinKrakow.pl, 2 Apr. 2020, uainkrakow.pl/dodatokkwarantanna-domowa-oboviazkovyi-dlia-vsikh-khto-perebuvaie-na-karantyni/.

20. Deutsche Welle. "Coronavirus: New Data Collection Application Introduced in Germany: DW: 07.04.2020." DW.COM, www.dw.com/ru/коронавирус-в-фрг-представили-новое-приложение-для-сбора-данных/a-53048057.

21. Deutsche Welle. "Smartphone Against Coronavirus: How to Control Self-Isolation In Example 5 Countries (22.04.2020): DW: 22.04.2020.” DW.COM, www.dw.com/uk/смартфон-проти-коронавірусу-як-контролюють-самоізоляцію-на-прикладі-5-країн$22042020 / \mathrm{av}-53209342$. 